\title{
Chemical Methods to Improve Seed Germination and Seedling Growth of Honey Locust (Gleditsia triacanthos L.)
}

\author{
Liviu HOLONEC, Oana VIMAN, Steluta M. SîngEORZAN, Petru TRUȚA, Alina M. TRUȚA*
}

Department of Forestry, University of Agricultural Sciences and Veterinary Medicine Cluj-Napoca, 3-5 Mănăștur St., 400372, Romania

*Corresponding author: Alina M. TRUȚA e-mail: alina_vilcan@yahoo.com

\section{RESEARCH ARTICLE}

\begin{abstract}
The present study aimed to improve the seed germination and plantlet development of honey locust (Gleditsia triacanthos) using two types of edaphic substrate (peat and peat+sand) and different chemical substances. Breaking physical dormancy for some forest seeds is a challenge for researchers and forest managers in order to obtain a homogeneous germination on larger areas. Germination percentage of honey locust seeds were investigated by using different chemical treatments as follows: calcium hydroxide; concentrated solution of sodium 4-nitrophenolate; solution with a content of auxines; copper sulphate; potassium permanganate and concentrated sulfuric acid. The highest percentage of seed germination was obtained when the seeds were immersed in an aqueous solution of sulfuric acid (14\%), followed by $12.5 \%$ (concentrated solution of sodium 4 nitrophenolate) and $12.3 \%$ (solution with a content of auxins). The lowest values (5\%) were recorded when copper sulphate was used. Regarding the different types of studied substrates, the highest percentage of germination was obtained on peat + sand. As regards to seedling development, the highest values were obtained on the peat + sand substrate, with seeds treated with sulfuric acid $(15.0 \mathrm{~cm})$. The concentrated solution of sodium 4-nitrophenolate and solution with auxins recorded also high values, $15.2 \mathrm{~cm}$, respectively $14.9 \mathrm{~cm}$. The lowest values for seedling height $(11 \mathrm{~cm})$ was noted when seeds were treated with potassium permanganate.
\end{abstract}

Keywords: chemical substances; germination; recipients; seedlings; seeds.

Received: 18 October 2020 Accepted: 29 March 2021 Published: 14 May 2021

DOI:

15835/buasvmen-hort:2020.0060

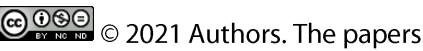
published in this journal are licensed under the Creative Commons Attribution-NonCommercialNoDerivatives 4.0 International License
}

\section{INTRODUCTION}

Honey locust (Gleditsia triacanthos L.,) is a leguminous tree from the Cesalpiniaceae family, originating from south-eastern part of North America, where its territory includes also the black locust, varying from South Ontario to Texas (Little, 1971; Cronk and Fuller, 1995). In the western part of the United States honey locust behaves as an invading species (Schnabel et al.,1991; Schnabel and Hamrick, 1990a), sometimes it reappears in forests (woodlands and early successional habitats) with Madura pomifera (Csurhes and Kriticos, 1994) and Robinia pseudoacacia.

Gleditsia triacanthos was introduced in large areas in Europe in 1700, presenting a high interest in parks as ornamental species, for protection of shelterbelts, along roads and fields and as barrier against wind (Ferus, 2013; Singh et al., 1991). It can be cultivated successfully in areas with air pollution (Ertekin and Kirdar, 2010), as hedges, as well as a component of flooding forests (György, 2007; Haraszthy, 2001). Although it is able to tolerate most soil types, including soils that are moderately saline, $G$. triacanthos grows most prolific on fertile, alluvial soils with a pH of 6.0-8.0 (Nas, 1980). The plant develops an extended lateral root system (Bedker and Blanchette, 1983). There is good growth in areas receiving $500 \mathrm{~mm}$ to $1500 \mathrm{~mm}$ annual rainfall (Nas, 1980) 
although the plant has been reported to survive also in areas receiving annual rainfall up to $355 \mathrm{~mm}$ (Mitchell, 1978).

Due to its vast territory, it is seen in many places as an invasive species (Gojdičová et al., 2002; Balogh et al., 2004), causing extreme complications in Argentinian Pampa grasslands and central natural forests, where a large effort in ecological research has been paid (Chaneton et al., 2004; De Viana and Speroni, 2003; Marco and Paez, 2000).

Gleditsia triacanthos $\mathrm{L}$. is a deciduous tree with heights that can reach even $45 \mathrm{~m}$ in its origin country, but in Romania does not exceed normally 20-25 m. The stem is straight enough, provided with large thorns upon 10-15 $\mathrm{cm}$, simple or with 1 (2-3) ramification, very rigid. The fruits of honey locust are flatten pods, often twisted, of 30$40 \mathrm{~cm}$ length, indehiscent (Blair, 1990; Brown and Kirkman, 1990). The seeds are brown, flatten, with very hard tegument, surrounded by a softer part and with a sweet taste, characteristics that attract animals (Vines, 1960; Burton and Bazzaz, 1991).

From ecological point of view, this species is tolerant to high temperatures (Graves et al., 1991; Graves and Wilkins, 1991; Godoy et al., 2011), resistant to drought and to the presence of salts in soil (Graves and Wilkins, 1991; Burton and Bazzaz, 1991; Burton and Bazzaz, 1995; Ertekin and Kirdar, 2010), loving the light, it presents a moderate to rapid growth speed (Burner et al., 2005). Recent studies show that it is a tolerant species to industrial and transport emissions (Benčat', 1982), relatively high resistance to low reaction of soil until pH 5 (Schindelbeck and Riha, 1988).

Generally, the reproduction through seeds is the easiest and most advantageous method of honey locust cultivation, but, without previous treatments, germination is low because of physiological rest induced by the impermeable tegument that covers the seed (Davies and Macfarlane, 1979; Geneve, 2008; Singh et al., 1991; Sîncrăian et al., 2013). In forestry practice different chemical and mechanical treatments are used, to improve the germination percentage. Masaka and Yamada (2009) obtained the highest germination rates (45.3\%) through sinking of seeds in boiled water at temperatures of $60^{\circ} \mathrm{C}$, for 3 hours. Also, Basbag et al. (2010) obtained the highest germination rates (25.5\%) through sinking of $G$. triacanthos seeds in boiled water at temperatures of $50^{\circ} \mathrm{C}$, for 30 minutes. Basbag et al. (2009) obtained germination rates between 8.39 and $29.52 \%$ for Capparis ovata seeds through application of different temperatures and durations.

Besides this scalding method, in practice is also enough using the chemical method, through sinking of seeds for 60 minutes in concentrated sulfuric acid, then washing in cold water, and then drying them in room at adjusted temperature, for 24 hours (Asl et al., 2011; Kheloufi, 2017).

Another successful method is the seed scarification when dried seeds are taken and placed in a metallic recipient with gravel. The recipient is strongly agitated, so that the tegument of seeds is scratched (Usberti and Martines, 2007).

The aim of this study was to evaluate the seeds germination of honey locust and the development of plants, through application of some chemical treatments, using two types of substrate (peat and peat+sand).

\section{MATERIALS AND METHODS}

\section{The biological material}

The study was accomplished in the greenhouse of University of Agricultural Sciences and Veterinary Medicine, ClujNapoca (Romania). Honey locust (Gleditsia triacanthos L.) seeds were used as biological material from trees grown in Mihai Viteazu nursery, Turda (altitude: $350 \mathrm{~m}$, latitude: N46 $34^{\prime} 15^{\prime \prime}$ and longitude: E23 ${ }^{\circ} 46^{\prime} 45^{\prime \prime}$ ), harvested in October 2018.

The seeds separated from pods were washed in tap water, then dried for two days at room temperature, after which they were sown. Previously, the main characteristics of the seeds (length, diameter and weight) were analysed.

\section{The study of germination}

The percentage of seed germination and the seedling growth were analyzed on two types of substrate: peat and sand+peat. The germination percentage of honey locust seeds were investigated using six chemical treatments, with different solutions (Table 1 ).

After each treatment, all seeds were immersed for 30 minutes in bidistilled water, and then sown in bloc type recipients, consisting each of 60 alveolaes, using two types of edaphic substrate (peat and peat+sand).

For each variant 50 seeds were used in four repetitions, totally 1.200 seeds were analysed. The weight of 1.000 seeds was of $160.4 \mathrm{~g}$. The germinated seeds were counted periodically starting with $7^{\text {th }}$ day until $30^{\text {th }}$ day, the selective criteria of germination being the radicle growth with $2 \mathrm{~mm}$.

Seed germination was expressed by the percentage of germination, which indicates the proportion, in digits, of the seeds that produced seedlings considered normal, under the conditions and period specified in the SR 1908/2004 standard. At the moment of transplantation, measurements were made regarding seedlings height, 
diameter and the number of leaves. The height was measured with graded ruler and the diameter was measured with sliding callipers.

Table 1. Characteristics of the two parts of the study (germination using different stimulants and germination using different types of substrate)

\begin{tabular}{|c|c|c|c|}
\hline $\begin{array}{c}\text { Varian } \\
\mathrm{t}\end{array}$ & Treatment & $\begin{array}{c}\text { Duration of treatment } \\
\text { (seeds soaked in diluted } \\
\text { solution) }\end{array}$ & Concentration \\
\hline V1 & $\begin{array}{l}\text { Ca }(\mathrm{OH})_{2} \\
\text { Calcium hydroxide }\end{array}$ & 17 hours & $20 \mathrm{~g} \mathrm{Ca}(\mathrm{OH})_{2}$ in $0.5 \mathrm{l}$ water \\
\hline $\mathrm{V} 2$ & $\begin{array}{l}\mathrm{C}_{6} \mathrm{H}_{4} \mathrm{NNaO}_{3} \\
\text { Sodium 4-nitrophenolate }\end{array}$ & 8 hours & $\begin{array}{c}1: 2000(0.75 \mathrm{ml} \text { active } \\
\text { substance in one liter tap water })\end{array}$ \\
\hline V3 & $\begin{array}{l}\text { C18H32O5 } \\
\text { Auxines }\end{array}$ & 8 hours & $1 \mathrm{ml}$ active substance in $0.6 \mathrm{l}$ water \\
\hline $\mathrm{V} 4$ & $\begin{array}{l}\mathrm{CuSO}_{4} \\
\text { Copper sulfate }\end{array}$ & 24 hours & $\begin{array}{c}1 \mathrm{~g} \mathrm{CuSO}_{4} \\
\text { in } 0.5 \text { l water }\end{array}$ \\
\hline V5 & $\begin{array}{l}\mathrm{KMnO}_{4} \\
\text { Potassium permanganate }\end{array}$ & 24 hours & $1.25 \mathrm{~g} \mathrm{KMnO}_{4}$ in $0.5 \mathrm{l}$ water \\
\hline V6 & $\begin{array}{l}\mathrm{H}_{2} \mathrm{SO}_{4} \\
\text { Sulfuric acid } \\
\end{array}$ & 30 minutes & concentrated sulfuric acid- $98 \%$ \\
\hline
\end{tabular}

\section{Data Analyses}

Analysis of variance (ANOVA) was used to compare the mean of germination affected by different types of chemical solutions and different types of substrates.

Significant differences among treatments were tested by one-way ANOVA at the $95 \%$ confidence level, and post hoc comparisons were made using the Tukey HSD test at $\mathrm{p}<0.05$ (Sestrass, 2018).

For germination data, a two-way ANOVA, with treatments and edaphic substrate as the main factors, was performed. Significance of differences between the main factors from the ANOVA analyses were evaluated with a Student-Newman-Keuls multiple range test $(\mathrm{p}<0.05)$.

\section{RESULTS AND DISCUSSIONS}

The characteristics of the seeds regarding the weight, diameter and length were represented as a boxplot diagram (Figure 1; Table 2). Regarding the length of the seeds, the minimum was $5.92 \mathrm{~mm}$, the maximum was 9.83 $\mathrm{mm}$, and the average was $7.59 \mathrm{~mm}$. In terms of seed diameter, the minimum was $4.43 \mathrm{~mm}$ and the maximum 6.91 $\mathrm{mm}$, and the seeds weighed $0.11 \mathrm{~g}$ (Figure 1; Table 2).

According to the literature, larger seeds have a higher germination rate because they contain more resources to support germination (Kheloufi et al., 2018; Long et al., 2015) and healthier seedlings (Kheloufi et al., 2018; Pedrol et al., 2018).

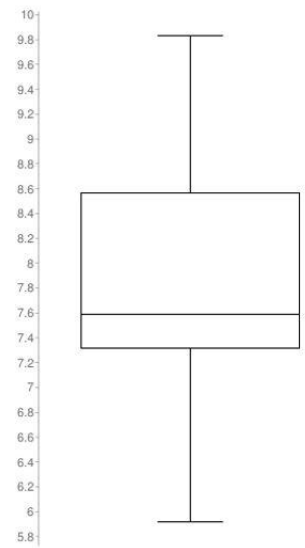

Length (mm)

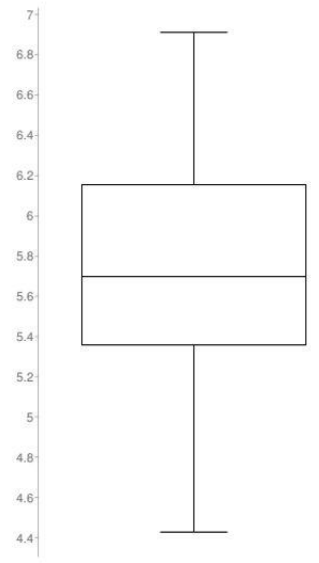

Diameter (mm)

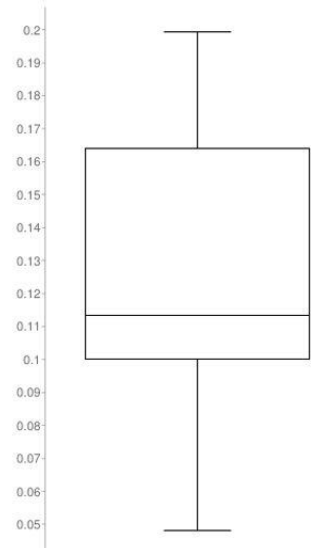

Weight (g)

Figure 1. Boxplot representation of the seed characteristics harvested from G. triacanthos 
Seed propagation is a method of reproduction of particular importance, because it maintains the genetic diversity of different populations. The seed is considered germinable if biochemical transformations and physiological processes can take place inside, starting the embryonic activity and determine the growth and development of the new seedling. The germination capacity of seeds can be established, first of all, according to the healthy appearance and the way in which they react to certain physical or chemical treatments (Koornneef et al., 2002).

Table 2. Characteristics of the seeds harvested from G. triacanthos

\begin{tabular}{cccc}
\hline Statistic & Length $(\mathrm{mm})$ & Diameter $(\mathrm{mm})$ & Weight $(\mathrm{g})$ \\
\hline $\mathrm{q} 1$ & 7.32 & 5.35 & 0.10 \\
\hline min & 5.92 & 4.43 & 0.04 \\
\hline median & 7.59 & 5.70 & 0.11 \\
\hline $\max$ & 9.83 & 6.91 & 0.19 \\
\hline $\mathrm{q} 3$ & 8.56 & 6.15 & 0.16 \\
\hline
\end{tabular}

Regarding the germination of honey locust seeds, using peat as a soil substrate, it can be observed that superior values were recorded in V2 (10.7\%) and V6 (11.3\%), where the seeds were treated with concentrated solution of sodium 4-nitrophenolate and sulfuric acid. The lowest values were recorded for variant V4 (5\%), where the seeds were treated with $\mathrm{CuSO}_{4}$ (Figure 2a).

Germination of seeds using peat+sand as edaphic substrate, registered higher values in variant V6 (seeds treated with sulfuric acid) than in the other variants. Lower values were recorded for variant V4 (5\%). The variants V2 (concentrated solution of sodium 4-nitrophenolate) and V3 (solution with auxins) achieved significantly superiors values comparing to $\mathrm{V} 5\left(\mathrm{KMnO}_{4}\right)$ and $\mathrm{V} 1$ (calcium hydroxide) (Figure $2 \mathrm{~b}$ ).

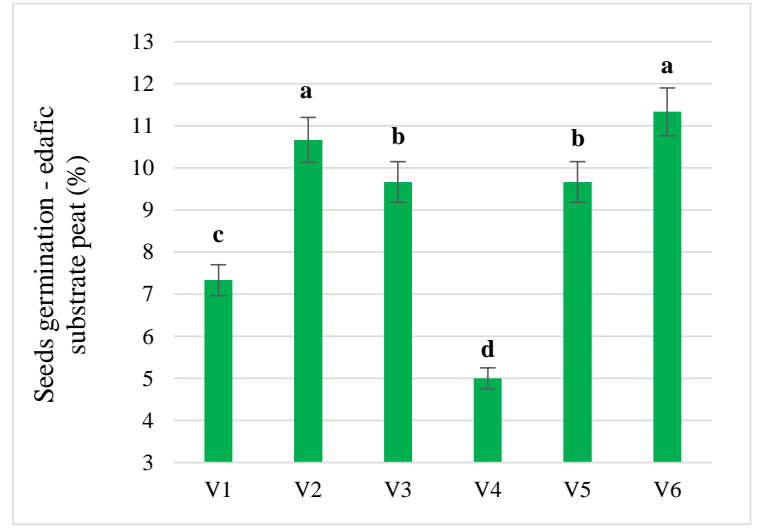

(a)

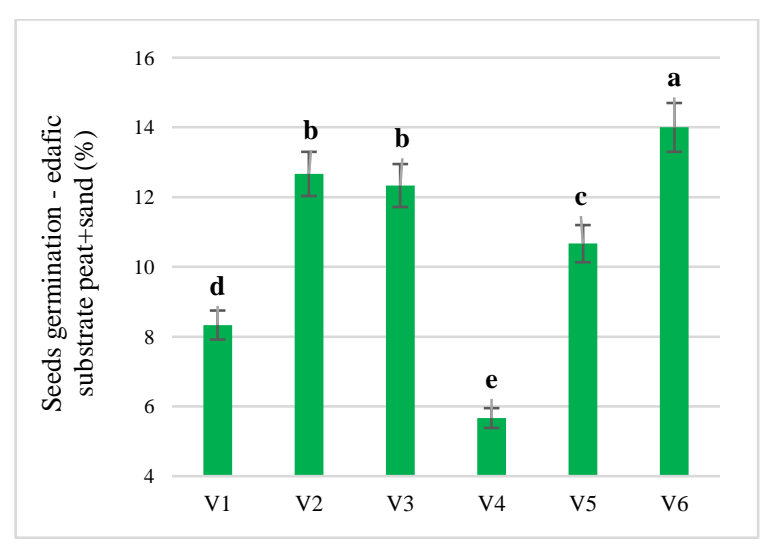

(b)

Figure 2. The Influence of chemical treatments on honey locust seed germination, using different edaphic substrates. (a) peat; (b) peat and sand. V1-calcium hydroxide solution; V2-concentrated aqueous solution of sodium paranitrofenolate; V3-aqueous solution with a content of auxines; V4-solution copper sulfate ( $\left.\mathrm{CuSO}_{4}\right)$; V5-solution with a potasium permanganate $\left(\mathrm{KMnO}_{4}\right)$; V6-concentrated sulfuric acid $\left(\mathrm{H}_{2} \mathrm{SO}_{4}\right)$

Based on the literature, the seeds of several species, including honey locust are covered with a hard coat which is a barrier to water imbibition (Singh et al., 1991) and the seeds need chemical treatments or scarification.

Different studies reported a 100\% germination of honey locust scarified seeds in a maximum of 60 days, while unscarified seeds, sown directly in the field germinated after two or even three years (Burton and Bazzaz, 1991).

Treatment of honey locust seeds with sulfuric acid, with concentrated solution of sodium 4-nitrophenolate, solution with auxins and solution with $\mathrm{KMnO}_{4}$ significantly improved seed germination. These results are in agreement with Basbag et al. (2009); Singh et al. (1991); Roman et al. (2020); Asl et al. (2011).

Regarding the development and growth of seedlings obtained from seeds, the results varied considerably, depending on the treatment variant and the type of substrate (Figure 3 and Figure 4).

As regards of seedling development using peat as edaphic substrate, the seedling height recorded the highest values in variants V2, V3, respectively V6, where the seeds were treated with concentrated solution of sodium 4- 
nitrophenolate, solution with auxins and sulfuric acid, while the lowest values were recorded in variant V1 (seeds treated with calcium hydroxide) (Figure 3). Regarding the seedling diameter, the variants V2, V3, respectively V6 registered high values within the studied variants. Leaf number per seedling recorded the greatest value in V6 variant (Figure 3).

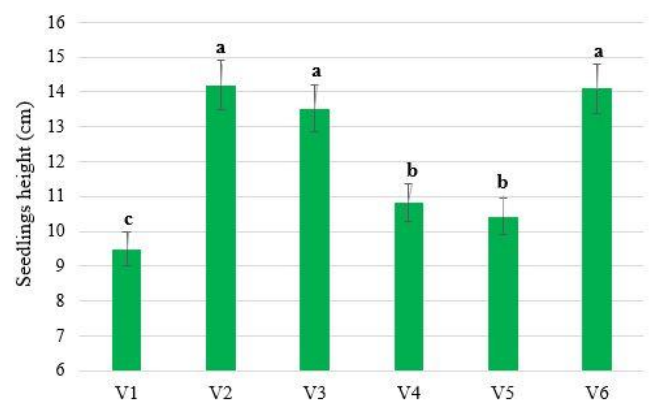

(a)

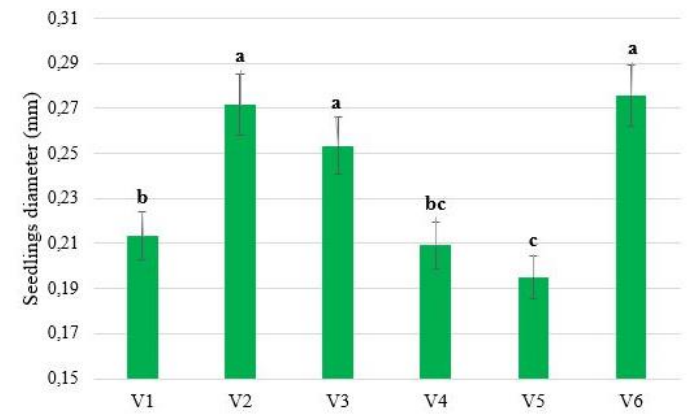

(b)

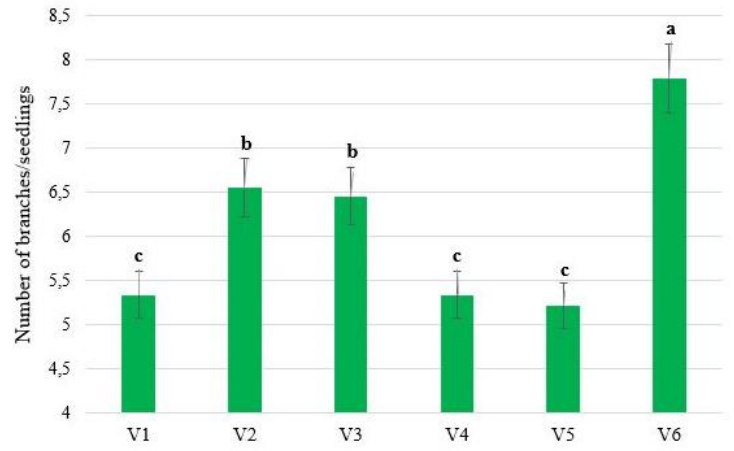

(c)

Figure 3. The main characteristics of G. triacanthos seedlings using peat. (a) Seedlings' height; (b) Seedlings' diameter; (c) Number of branches/seedling. V1-calcium hydroxide solution; V2-concentrated aqueous solution of sodium paranitrofenolate; V3-aqueous solution with a content of auxines; V4solution copper sulfate (CuSO4); V5-solution with a potasium permanganate (KMnO4); V6-concentrated sulfuric acid (H2SO4)

Regarding the development of seedlings using peat + sand as edaphic substrate, it can be observed that higher values were recorded for all the analyzed characteristics (Figure 5), compared to seedling development using peat as edaphic substrate (Figure 4). 


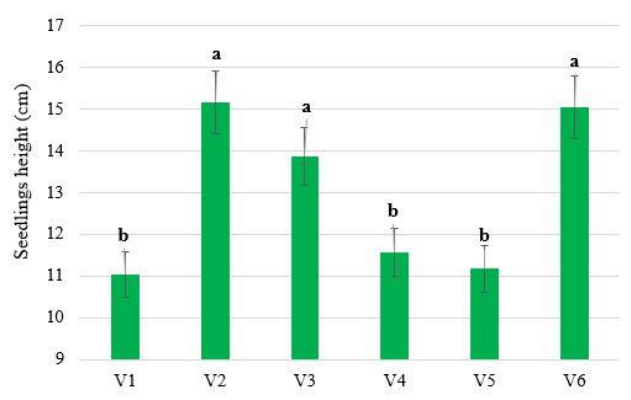

(a)

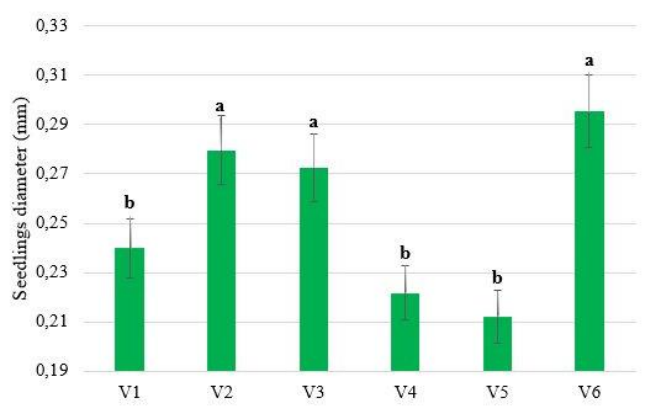

(b)

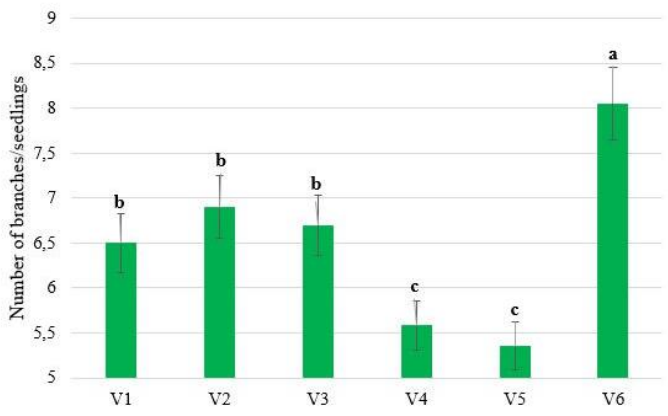

(c)

Figure 4. The main characteristics of G. triacanthos seedlings using peat+sand. (a) Seedlings' height; (b) seedlings' diameter; (c) Number of branches/seedling. V1-calcium hydroxide solution; V2-concentrated aqueous solution of sodium paranitrofenolate; V3-aqueous solution with a content of auxines; $\mathrm{V} 4$-solution copper sulfate $\left(\mathrm{CuSO}_{4}\right)$; $\mathrm{V} 5$-solution with a potasium permanganate $\left(\mathrm{KMnO}_{4}\right)$; V6-concentrated sulfuric acid $\left(\mathrm{H}_{2} \mathrm{SO}_{4}\right)$

The height of the seedlings in variant V2 was $15.2 \mathrm{~cm}$, in variant V6 was $15.0 \mathrm{~cm}$, and the smallest value was registered in variant $\mathrm{V} 1$, as $11.0 \mathrm{~cm}$. Also, for the other two characteristics, the diameter and the number of leaves, the highest values were reached in the sixth variant, seeds treated with sulfuric acid, and the lowest values were registered in the fifth variant, seeds treated with $\mathrm{KMnO}_{4}$ (Figure 5).

Following the statistical results the seeds treated with $\mathrm{KMnO}_{4}$, had a medium to high germination percentage, but the seedling development recorded the lowest values, which is not recommended for forestry practice.

The treatment with the best results in terms of seed germination and seedling development was the sulfuric acid followed by concentrated solution of sodium 4-nitrophenolate and solution with auxins.

\section{CONCLUSIONS}

The present paper underlined several findings regarding seeds treatment before sowing, using different chemical substances. The choice of substances with major influence on germinative processes and their application will lead to increased germination percentage and stronger growth of honey locust seedlings.

Author Contributions: L.H. and A.M.T. Conceived and designed the analysis; O.V., S.M.S. and P.T. Collected the data; L.H. and A.M.T. Contributed data or analysis tools; L.H. and A.M.T. Performed the analysis; L.H., A.M.T. and O.V. Wrote the paper. All authors read and approved the final manuscript. 
Funding Source: This research did not receive any funding.

Acknowledgments: This research did not receive any specific grant from funding agencies in the public, commercial, or not-for-profit sectors.

Conflicts of Interest: The authors declare that there are no conflicts of interest related to this article.

\section{REFERENCES}

1. Asl MB, Sharivivash R, Rahbari A (2011). Effect of Different Treatments on Seed Germination of Honey Locust (Gleditschia triacanthos). Modern Applied Science, 5(1): 200-204.

2. Balogh L, Dancza I, Király G (2004). Actual list of neophytes in Hungary and their classification according to their success. In Mihály, B, BottaDukát Z (eds). Biological invasions in Hungary - invasive plants. Budapest: Természet Búvár Alapítvány Kiadó, p. 61-92.

3. Basbag M, Toncer O, Basbag S (2009). Effects of different temperatures and duration on germination of caper (Capparis ovata) seeds. Journal of Environmental Biology, 30(4): 621-624.

4. Basbag M, Aydin A, Ayzit D (2010). The Effect of Different Temperatures and Durations on the Dormancy Breaking of Black Locust (Robinia pseudoacacia L.) and Honey Locust (Gleditsia triacanthos L.) Seeds. Notulae Scientia Biologicae, 2(4): 125-128.

5. Bedker PJ, Blanchette RA (1983). Development of cankers caused by Neetria cinnabarina on honey locusts after root pruning. Plant Disease, 67: 1010-1013.

6. Benčat' F (1982). Atlas of exotic tree species spreading in Slovakia. Bratislava: Veda, p. 368.

7. Blair RM (1990). Gleditsia triacanthos L., honeylocust. In: Burns RM, Honkala BH, tech. coords. Silvics of North America. Volume 2, Hardwoods. Agric. Handbk. 654. Washington, DC: USDA Forest Service: 358B364.

8. Brown CL, Kirkman LK (1990). Trees of Georgia and adjacent states. Portland, OR: Timber Press. 292 p.

9. Busse WF (1930). Effect of Low Temperatures on Germination of Impermeable Seeds. Botanical Gazette, 89(2): 169-179.

10. Burton PJ, Bazzaz FA (1991). Tree seedling emergence on interactive temperature and moisture gradients and in patches of old-field vegetation. American Journal of Botany, 78: 131-149.

11. Burton PJ, Bazzaz FA (1995). Ecophysiological responses to tree seedlings invading different patches of oldfield vegetation. Journal of Ecology, 83: 92-112.

12. Burner DM, Pote DH, Ares A (2005). Management effects on biomass and foliar nutritive value of Robinia pseudoacacia and Gleditsia triacanthos f. inermis in Arkansas, USA. Agroforestry Systems, 65: 207-214.

13. Chaneton EJ, Mazia CN, Machera M, Uchitel A, Ghersa CM (2004). Establishment of honey locust (Gleditsia triacanthos) in burned Pampean grasslands. Weed Technology, 18: 1325-1329.

14. Csurhes SM, Kriticos D (1994). Gleditsia triacanthos L. (Caesalpiniaceae), another thorny, exotic fodder tree gone wild. Plant Protection Quarterly, 9(3): 101-105.

15. Cronk QCB, Fuller JL (1995). Plant invaders: the threat to natural ecosystems. Chapman and Hall, London.

16. Davies DJG, Macfarlane RP (1979). Multiple-purpose trees for pastoral farming in New Zealand: with emphasis on tree legumes. New Zealand Agricultural Science, 13(4): 177-186.

17. De Viana ML, Speroni FC (2003). Invasion of Gleditsia triacanthos L. (Fabaceae) in San Lorenzo mountain forest (Northwest Argentina). In Child L, Brock JH, Brundu G, Prach K, Pyšek P, Wade PM, Williamson M (eds). Plant invasions: ecological threats and management solutions. Loughborough, 6th International conference on the ecology and management of alien plant invasions. Leiden: Buckhuys, p. 277-287.

18. Ertekin M, Kirdar E (2010). Effects of seed coat colour on seed characteristics of honeylocust (Gleditsia triacanthos). African Journal of Agricultural Research, 5: 2434-2438.

19. Ferus P, Barta M, Konôpková J, Turčeková S, Maňka P, Bibeň T (2013). Diversity in honey locust (Gleditsia triacanthos L.) seed traits across Danube basin. Folia Oecolgica, 40(2): 163-169.

20. Geneve RL (2008). A Closer Look at Seed Germination and Dormancy. Department of Horticulture University of Kentucky, Lexington, Kentucky 561-565. http://www.ipps.org/SouthernNA/pdf/ 2008papers/Geneve-Bob.pdf.

21. Godoy O, de Lemos JP, Valladares F (2011). Invasive species can handle higher leaf temperature under water stress than Mediterranean natives. Environmental and Experimental Botany, 71: 207-214.

22. Gojdičová E, Cvachová A, Karasová E (2002). List of alochthonous, invasive and expansive vascular plant species of Slovakia. Ochr. Prír., 21: 59-79.

23. Graves WR, Wilkins LC (1991). Growth of honey locust seedlings during high root-zone temperature and osmotic-stress. Hortscience, 26: 1312-1315.

24. 23. Graves WR, Joly RJ, Dana MN (1991). Water-use and growth of honey locust and tree-of-heaven at high rootzone temperature. Horticultural Science, 26: 1309-1312. 
25. György Z (2007). To the biology of the honey locust seed beetle, Megabruchidius tonkineus (Pic, 1904) (Coleoptera: Chrysomelidae: Bruchinae). Folia Entomologica Hungaria, 68: 89-96.

26. Haraszthy L (2001). The floodplain forests in Hungary. In Klimo E, Hager H (eds). The floodplain forests in Europe: current situation and perspectives. Leiden: Brill, p. 17-24.

27. Kheloufi A (2017). Germination of seeds from two leguminous trees (Acacia karroo and Gleditsia triacanthos) following different pre-treatments. Seed Sci Technol, 45: 1-4.

28. Kheloufi A, Mansouri L, Aziz N, Sahnoune M, Boukemiche S, Ababsa B (2018). Breaking seed coat dormancy of six tree species. Reforesta, (5): 4-14.

29. Koornneef M, Bentsink L, Hilhorst HWM (2002). Seed dormancy and germination. Current Opinion in Plant Biology, 5(1): 33-6.

30. Little EL (1971). Atlas of US Trees. Volume 1. United States Department of Agriculture Forest Service, Miscellaneous Publication Number 1146. (United States Government Printing Office, Washington DC).

31. Long RL, Gorecki MJ, Renton M, Scott JK, Colville L, Goggin DE, Finch-Savage WE (2015). The ecophysiology of seed persistence: a mechanistic view of the journey to germination or demise. Biological Reviews 90(1): 31-59.

32. Marco DE, Paez SA (2000). Invasion of Gleditsia triacanhos in Lithraea ternifolia Montane forests of central Argentina. Env Manag, 26: 409-419.

33. Masaka K, Yamada K (2009). Variation in germination character of Robinia pseudoacacia L. (Leguminosae) seeds at individual tree level. Journal of Forest Research, 14: 16-177.

34. Mitchell D (1978). Notes compiled by the Nelson branch of the New Zealand Tree Crops Association. New Zealand Journal of Agriculture, 21-22.

35. Nas (1980). Firewood Crops: Shrub and Tree Species for Energy Production. National Academy of Sciences, Washington DC, 1: 36-37.

36. Pedrol N, Puig CG, López-Nogueira A, Pardo-Muras M, González L, Souza-Alonso P (2018). Optimal and synchronizedgermination of Robinia pseudoacacia, Acacia dealbata and other woody Fabaceae using a handheld rotary tool: concomitant reduction of physical and physiological seed dormancy. Journal of Forestry Research 29(2): 283-90.

37. Roman AM, Morar IM, Truța AM, Dan C, Sestraș AF, Holonec L, Ioraș F, Sestraș RE (2020). Trees, seeds and seedlings analyses in the process of obtaining a quality planting material for black locust (Robinia pseudoacacia L.). Notulae Scientia Biologicae,12(4): 940-958.

38. Schindelbeck RR, Riha SJ (1988). Soil acidity, and the growth, biomass partitioning and leaf mineral composition of honey locust (Gleditsia triacanthos L.) seedlings. Tree Physiology, 4: 361-369.

39. Schnabel A, Hamrick JL (1990a). Organization of genetic diversity within and among populations of Gleditsia triacanthos (Leguminosae). American Journal of Botany 7: 1060-1069.

40. Schnabel A, Laushman RH, Hamrick JL (1991). Comparative genetic structure of two co-occurring tree species, Maclura pomifera (Moraceae) and Gleditsia triacanthos (Leguminoseae). Heredity, 67: 357-364.

41. Sefik Y (1995). Agroforestry. Karadeniz Technical University, Faculty of Forestry Pubs. No. 176/21, Trabzon, Turkey.

42. Sestraș FA (2018). Biostatistics and experimental design in forestry, Didactic manual. Ed. AcademicPres, ClujNapoca.

43. Singh DP, Hooda MS, Bonner FT (1991). An evaluation of scarification methods for seeds of two leguminous trees. New Forests, 5(2): 167-173.

44. Sîncrăian I, Criveanu HR, Inoan SL (2013). Observations Regarding the Influence of A.D. Bio-Phyto-Modulators on Germination and Growing of the Picea abies (L.) Karst (Spruce) and Robinia pseudocacia L. (Locust, Acacia). Bulletin UASVM Horticulture, 70(1): 217-222.

45. Usberti R, Martines L (2007). Sulfuric acid scarification effects on Brachiaria brizantha, B. humidicola and Panicum maximum seed dormancy release. Revista Brasileira de Sementes, 29(2): 143-147.

46. Vines RA (1960). Trees, shrubs, and woody vines of the Southwest. Austin: University of Texas Press. 1104 p. 